\title{
A EDUCAÇÃO PARA O TRÂNSITO COMO FERRAMENTA DE OBEDIÊNCIA AOS PRINCÍPIOS DA EFICIÊNCIA E DA DIGNIDADE DA PESSOA HUMANA
}

\section{EDUCATION FOR TRANSIT AS A TOOL OF OBEDIENCE TO THE PRINCIPLES OF EFFICIENCY AND THE DIGNITY OF THE HUMAN PERSON}

\begin{abstract}
Paulo Rangel Araújo Ferreira Bacharel em Direito pela Universidade Estadual do Piauí - UESPI (2010-2014), estuda Pós-Graduação Lato Sensu em Direito Público pela Faculdade de Direito Damásio de Jesus, é pesquisador atuante na Grande-Área Direito Público (Constitucional e Administrativo/Trânsito) com projetos de pesquisa desenvolvidos na área.
\end{abstract} araujo_rangel@hotmail.com

ITAMAR DA SILVA SANTOS FILHO Doutor em "Derechos y Garantías del Contribuyente" (2012) pela Universidad de Salamanca-España. Graduação em Direito pela Universidade de Fortaleza-Unifor, especialista em Direito Tributário e Processual Civil pela Universidade de Fortaleza, Mestre em Direito Econômico e Desenvolvimento pela Universidade Cândido Mendes.

Professor do Curso de Direito da Faculdade Maurício de Nassau - FAP - Campus Parnaíba e do Curso de Direito da Universidade Estadual do Piauí - UESPI, campus Piripiri.

itamarsfilho@ig.com.br

\section{RESUMO}

Mais de 30 mil pessoas morrem vítimas de acidentes de trânsito no Brasil a cada ano. Uma funesta realidade para a qual não há medidas realmente efetivas sendo tomadas. Há um Estado omisso e uma legislação subefetivada que, embora preveja a Educação para o Trânsito como ferramenta essencial para a formação de um condutor responsável, não a efetiva, e torna o diploma de trânsito apenas mais uma lei sem efetividade no grande rol de leis brasileiras. Este trabalho consiste em uma pesquisa bibliográfica e objetiva apresentar o tema da Educação para o Trânsito como ele está previsto no Código de Trânsito Brasileiro (CTB) e demais legislações atinentes ao tema, demonstrando-se suas possibilidades de efetivação. Tal caminho levaria a um condutor mais consciente, à valorização da vida humana, à diminuição da perda precoce da população economicamente ativa, por sua vez, encolher-se-iam os gastos hospitalares custeados pela Máquina Pública com as vítimas do trânsito.

Palavras-chave: Código de Trânsito Brasileiro; Educação Para o Trânsito; Princípio da Dignidade da Pessoa Humana; Princípio da Eficiência.

\begin{abstract}
More than 30 thousand people die victims of traffic accidents in Brazil each year. A grim reality for which there is no really effective measures being taken. There's a State omitted and under legislation take effect which, while providing for the Transit education as a tool for the formation of a responsible driver, not effective, and makes the degree of traffic just another law without effectiveness in the great rol of Brazilian law. This work consists of a bibliographical research and aims to introduce the topic of education for transit as it is planned in the Brazilian Transit Code (CTB) and other related legislation, demonstrating their effective possibilities. Such a path would lead to a more aware driver, the valuation of human life, the reduction of early loss of the economically active population, in turn, would shrink the hospital expenses defrayed by Public Machine with victims of traffic.
\end{abstract}

Keywords: Brazilian Traffic Code; Education for the Transit; Principle of Human Dignity; Principle of efficiency. 
A EDUCAÇÃO PARA O TRÂNSITO COMO FERRAMENTA DE OBEDIÊNCIA AOS PRINCÍPIOS DA EFICIÊNCIA E DA DIGNIDADE DA PESSOA HUMANA

Paulo Rangel araújo Ferreira, Itamar da Silva Santos Filho

\section{SUMÁRIO}

INTRODUÇAO; 1 DOS PRINCÍPIOS CONSTITUCIONAIS DA ADMINISTRAÇÃO PÚBLICA; 1.10 princípio da legalidade; 1.20 princípio da moralidade; 1.30 princípio da eficiência; 1.40 princípio da dignidade da pessoa humana; 2 DAS BASES LEGAIS DA EDUCAÇÃO PARA O TRÂNSITO; 2.1 Da constituição federal de 1988; 2.2 Do plano nacional de educação (PNE) e do plano nacional de educação em direitos humanos (PNEDH); 2.3 Do código de trânsito brasileiro (CTB); 2.4 Da lei de diretrizes e bases (LDB) e dos parâmetros curriculares nacionais (PCN); 3 DO TRÂNSITO EM NÚMEROS; 3.1 Das estatísticas mundiais; 3.2 Da evolução do número de acidentes no Brasil; 3.3 Do perfil das vítimas; 3.4 Dos custos hospitalares dos acidentes; CONCLUSÃO; REFERÊNCIAS.

\section{INTRODUÇÃO}

No decorrer de 30 anos (1980 a 2011) cerca de 1 milhão de pessoas morreram vítimas de acidentes de trânsito no Brasil, conforme dados oficiais do Ministério da Saúde (MS) e do Sistema de Informações Sobre Mortalidade (SIM) do ano de $2011^{1}$. Se compararmos estes dados com os conflitos no Vietnã, que duraram 20 anos (1955 a 1975), o número de mortos lá foi bem menor: 58.193 soldados americanos morreram no campo de batalha ${ }^{2}$.

Dados do Sistema de Informações Hospitalares (SIH) apontam que as internações hospitalares de vítimas do trânsito geraram ao Erário um gasto de 210,8 milhões no ano de 2011, respondendo os motociclistas por quase $50 \%$ deste total $(48,4 \%)$, avaliados em $\mathrm{R} \$$ 102.071.861,00, conforme Mapa da Violência no Trânsito do ano de 2013, publicação do Centro Brasileiro de Estudos Latino-Americanos (CEBELA) ${ }^{3}$.

Com base nos dados acima apresentados, não seria obtuso usar da metáfora "guerra no trânsito" para se referir à teratologia viária nacional que, atrelada à atuação da Administração Pública, servem de escopo para a inferência do que se propõe defender este tratado com o título “A Educação Para o Trânsito Como Ferramenta de Obediência aos Princípios da Eficiência e da Dignidade da Pessoa Humana".

o contrassenso que há entre os infortúnios do trânsito e os meios que a Administração Pública usa para saná-los não deixa dúvida de sua ineficiência, uma vez que, não há uma diminuição do número de mortes/acidentes ao longo dos anos ou uma melhora visível no

\footnotetext{
${ }^{1}$ WAISELFISZ, Julio J. Mapa da violência no trânsito. Rio de Janeiro, FLACSO Brasil; CEBELA, 2013. p. 20.

${ }^{2}$ OLIVEIRA, Alberto. Trânsito brasileiro mata quase como uma guerra do Vietnã a cada ano. Disponível em: <http://www.tribunadabahia.com.br/2012/12/26/transito-brasileiro-mata-quase-como-uma-guerrado-vietnam-cada-ano> Acesso: 23 out. 2014.

${ }^{3}$ WAISELFISZ, op. cit., p. 79.
} 
A EDUCAÇÃO PARA O TRÂNSITO COMO FERRAMENTA DE OBEDIÊNCIA AOS PRINCÍPIOS DA EFICIÊNCIA E DA DIGNIDADE DA PESSOA HUMANA

Paulo Rangel araújo Ferreira, Itamar da Silva Santos Filho

comportamento dos condutores e da forma que eles trafegam nas vias públicas do Estado brasileiro, a despeito de a legislação evoluir constantemente.

Assim, há que se buscar outros meios de resolver o problema. Uma alternativa legal, prevista na Carta Magna (artigos 23, XII e introduzido por meio da Emenda Constitucional (EC) $\mathrm{n}^{\circ}$ 82, publicada no Diário Oficial da União (DOU) em 17 de julho de 2014, o $\$ 10$ do art. $144^{4}$ ) e no CTB (artigos 74-79) é a oferta da Educação para o Trânsito nas escolas desde as séries iniciais, mediante ações coordenadas entre os órgãos e entidades do Sistema Nacional de Trânsito e de Educação, da União, Estados, do Distrito Federal e dos Municípios (art. 76 do CTB).

São objetivos deste trabalho: (I) apresentar a Administração Pública e os seus princípios; (II) Apresentar as bases legais da Educação para o Trânsito - Constituição da República Federativa do Brasil (CRFB) de 1988, o Código de Trânsito Brasileiro (CTB), o Plano Nacional de Educação, o Plano Nacional de Educação em Direitos Humanos (PNEDH), a Lei de Diretrizes e Bases (LDB) e os Parâmetros Curriculares Nacionais (PCN); (III) Apresentar os números advindos do trânsito, demonstrando-se a necessidade de se adotarem novas medidas.

O trabalho consiste em pesquisa bibliográfica-documental utilizando-se do método lógico-dedutivo, por meio do qual pretende-se demonstrar que um trânsito seguro, que privilegie a vida, será alcançado pela oferta da Educação para o Trânsito em tempo hábil, baseando-se na construção doutrinária, jurisprudencial e normativa.

\section{DOS PRINCÍPIOS CONSTITUCIONAIS DA ADMINISTRAÇÃO PÚBLICA}

0 artigo 37, caput da CRFB de 1988 traz, explicitamente, cinco princípios que deverão obrigatoriamente ser obedecidos pelo gestor público no manejo da coisa pública, são eles: o princípio da legalidade, o da impessoalidade, da moralidade, publicidade e o da eficiência.

No entanto, existem diversos outros princípios que, de igual modo, deverão ser obedecidos, seja em sede de Poder Executivo, Legislativo ou Judiciário, são os chamados princípios fundamentais, citados no texto constitucional em seus artigos $1^{\circ}$, incisos I ao $\mathrm{V}$ e 60 , $\S$ $4^{\circ}$, incisos I ao V, ambos dispondo sobre a proibição da mudança da forma de Estado, do voto

\footnotetext{
${ }^{4}$ BRASIL. Emenda Constitucional $n^{\circ}$ 82, de 17 de julho de 2014. Inclui o $§ 10$ ao art. 144 da Constituição Federal, para disciplinar a segurança viária no âmbito dos Estados, do Distrito Federal e dos Municípios. Disponível em: <http://www.senado.gov.br/atividade/materia/detalhes.asp?p_cod_mate=115833> Acesso: 24 out. 2014.
} 
A EDUCAÇÃO PARA O TRÂNSITO COMO FERRAMENTA DE OBEDIÊNCIA AOS PRINCÍPIOS DA EFICIÊNCIA E DA DIGNIDADE DA PESSOA HUMANA

Paulo Rangel araújo Ferreira, Itamar da Silva Santos Filho

direto, da separação dos poderes e, sobretudo, da garantia de acesso aos direitos e garantias individuais.

A República Federativa do Brasil tem como principais fundamentos as garantias individuais e a dignidade da pessoa humana, sendo referido princípio o núcleo de todo o ordenamento jurídico e de todos os demais princípios, não podendo, nehuma outra norma de qualquer ramo do direito versar em desacordo ou sobrepor-se a ele.

Portanto, os princípios da Administração Pública foram criados à luz do postulado da dignidade da pessoa humana, a este se subordinando e devendo, de igual modo, o Gestor da coisa pública agir de maneira que os atos da Administração Pública sejam legais, impessoais, morais, públicos e eficientes porque, além de o gestor ter feito só o que previa a lei, de forma impessoal, moral, transparente e eficiente, também, não feriu à dignidade da pessoa humana.

Importa acrescentar que para o presente trabalho somente será oportuno tecer comentários acerca dos princípios da legalidade, moralidade, eficiência e o da dignidade da pessoa humana no que tange a responsabilidade do gestor público.

\section{1 princípio da legalidade}

O princípio da legalidade deve ser o guia de toda a Administração Pública e, incorporado ao princípio da indisponibilidade do interesse público, deve vincular todos os atos do gestor público à lei, motivo pelo qual ele estará obrigado a agir somente no tocante à satisfação do bem comum, tal como está previsto na legislação, "enquanto este é da essência de qualquer Estado, de qualquer sociedade juridicamente organizada com fins políticos, aquele é específico do Estado de Direito, é justamente o que the qualifica e que the dá a identidade própria”. ${ }^{5}$

Claro deve estar que o princípio da legalidade, como descrito nas linhas acima, versa sobre o manejo da coisa pública e à atuação daquele escolhido para representar os interesses do povo, atuando no sentido de satisfazer às necessidades da coletividade e de ofertar serviços públicos de qualidade. Na esfera particular, o princípio que vige é outro, o da autonomia da vontade, previsto no art. $5^{\circ}$, inciso II da Carta Magna, não vinculando, necessariamente, o particular aos interesses coletivos, embora haja a necessidade, exemplificando, de os contratos particulares obedecerem a uma função social.

Essa necessidade de vinculação dos atos da Administração Pública à lei decorre do fato de que o administrador público não é dono da coisa pública, mas, tão somente,

${ }^{5}$ MELLO, Celso Antônio Bandeira de. Curso de direito administrativo. $27^{\text {a }}$ ed. rev. e atual. São Paulo: Malheiros, 2010. p. 99-100. 
A EDUCAÇÃO PARA O TRÂNSITO COMO FERRAMENTA DE OBEDIÊNCIA AOS PRINCÍPIOS DA EFICIÊNCIA E DA DIGNIDADE DA PESSOA HUMANA

Paulo Rangel araújo Ferreira, itamar da Silva Santos Filho

representante do povo, não estando, portando, a cargo dele decidir o que é ou não de interesse do povo, mas à lei, que, ao cumpri-la, estará obedecendo tanto ao princípio da legalidade quanto ao princípio da indisponibilidade do interesse público. ${ }^{6}$

Assim, cabe destacar, que a eficácia dos atos da Administração Pública ficam sujeitos ao que prescreve a lei e, uma vez eivados de ilegalidade, submeterá tanto o ato quanto o responsável por ele a sanções, podendo o ato ser declarado inválido e o gestor público responder administrativa, civil ou penalmente, ${ }^{7}$ ou seja, “diz-se que a administração pública, além de não poder atuar contra a lei ou além da lei, somente pode agir segundo a lei (a atividade administrativa não pode ser contra legem nem praeter legem, mas apenas secundum legem)". ${ }^{8}$

Por outro lado, sem negar a necessidade de vinculação administrativa ao princípio da legalidade, cabe acrescentar que nada impede que o administrador faça uso de sua discricionariedade frente a casos sem previsão legal. Apesar de a linha entre discricionariedade e arbitrariedade ser tênue, até mesmo nestes casos, há a necessidade de subordinação aos limites impostos pela lei à discricionariedade, buscando obediência ao princípio da legalidade e o controle da atuação, evitando que um ato discricionário se torne um ato arbitrário.

Marinela traça uma perfeita distinção entre um ato discricionário e um ato arbitrário quando expõe que:

Os primeiros são praticados tendo como base a conveniência e a oportunidade do interesse público, admitindo um juízo de valor por parte do agente público, com liberdade, estando essa restrita aos limites da regra legal. No lado oposto tem-se o ato arbitrário, que representa o abuso, ato praticado fora dos limites da norma, ato inválido, ilegal e que deve ser retirado da ordem jurídica. ${ }^{9}$

Além dos casos de discricionariedade, há as hipóteses em que o administrador da coisa pública poderá restringir o atendimento ao princípio da legalidade com base no texto constitucional, são elas: (I) as medidas provisórias, (II) o estado de defesa e o (III) estado de sítio. Insta reassaltar que as referidas medidas são excepcionais, mas autorizadas pela Lei Maior, desta forma o administrador público sempre estará vinculado ao ordenamento jurídico como um todo, aos princípios administrativos e até aos próprios atos administrativos.

\footnotetext{
${ }^{6}$ ALEXANDRINO, Marcelo et alii. Direito administrativo descomplicado. $22^{\mathrm{a}}$ ed. atual. São Paulo: Método, 2014. p. 13.

${ }^{7}$ MARINELA, Fernanda. Direito administrativo. $7^{\text {a }}$ ed. Salvador: JusPODIVM, 2013. p. 31.

${ }^{8}$ ALEXANDRINO, op. cit., p. 14.

${ }^{9}$ MARINELA, op. cit., p. 31.
} 
A EDUCAÇÃO PARA O TRÂNSITO COMO FERRAMENTA DE OBEDIÊNCIA AOS PRINCÍPIOS DA EFICIÊNCIA E DA DIGNIDADE DA PESSOA HUMANA

Paulo Rangel araújo Ferreira, itamar da Silva Santos Filho

\subsection{0 princípio da moralidade}

O princípio da moralidade também está previsto no caput do art. 37 da Constituição e tutela a moralidade jurídica, ligando-se à ideia de honestidade, "sendo frequente a asserção de que o princípio da moralidade complementa o princípio da legalidade, ou amplia materialmente a sua efetividade" ${ }^{10}$, resultando naquilo conhecido como princípio da juridicidade.

A moral jurídica, da qual trata o princípio da moralidade, difere da moralidade comum porque, enquanto esta se preocupa com uma distinção entre bem e mal ou aquilo que é bem visto como bom/ruim em uma determinada sociedade, aquela compõe-se não só de alinho de atitudes, mas também por probidade administrativa e interesses voltados para o bem comum, ligando-se, diretamente, com o princípio da impessoalidade. Logo, pode-se extrair que qualquer atuação pessoal - quando deveria ser impessoal - do administrador público, viola diretamente o princípio em comento e, porque não dizer, ao princípio da impessoalidade? São os chamados casos de improbidade administrativa, tão comuns na atualidade.

Por sua vez, embora haja autonomia entre o princípio da moralidade e a moral comum, desta ele não se distancia demasiadamente, pois, uma vez que o direito reflete a realidade, os seus princípio também inspiram-se nos padrões éticos da sociedade, logo, se a moral comum “[...] determina que se trate a outrem do mesmo modo que se apreciaria ser tratado, isto é, de modo virtuoso e honesto, o "outro" aqui pode, também, ser entendido como a sociedade inteira, a coletividade $[\ldots] " .{ }^{11}$

No texto constitucional, além do art. 37, o princípio da moralidade também aparece no art. $5^{\circ}$, inciso LXXIII, ao dispor que:

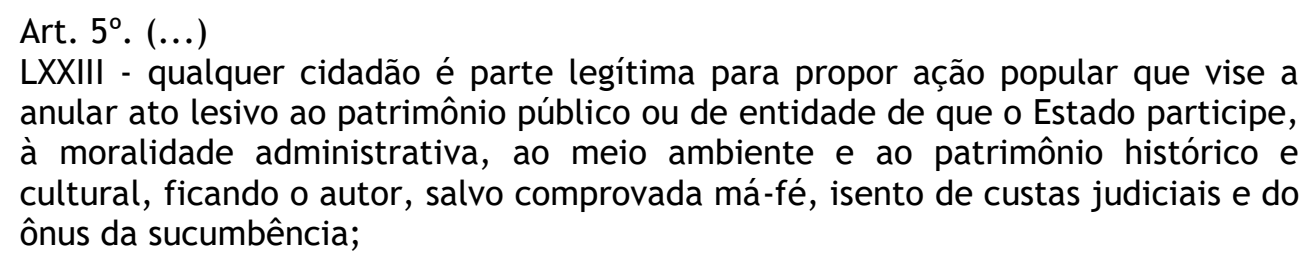

Extrai-se do supracitado inciso que o ato tido como contrário à moral será declarado nulo e não revogado. 0 que poderá ser feito por parte da própria Administração Pública no uso de outro princípio, o da autotutela, ou por meio do Poder Judiciário e das ações populares citadas no inciso acima.

\footnotetext{
${ }^{10}$ ALEXANDRINO, op. cit., p. 14.

${ }^{11}$ FREITAS. Juarez. O controle dos atos administrativos e os direitos fundamentais. $3^{\text {a }}$ ed. São Paulo: Malheiros: 2004. p. 55.
} 
A EDUCACÃO PARA O TRÂNSITO COMO FERRAMENTA DE OBEDIÊNCIA AOS PRINCÍPIOS DA EFICIÊNCIA E DA DIGNIDADE DA PESSOA HUMANA

Paulo Rangel araújo Ferreira, Itamar da Silva Santos Filho

Ademais, vale acrescentar, que há diversas outras previsões de controle de moralidade administrativa presentes no ordenamento jurídico pátrio, a exemplo da Lei $n^{\circ}$ 101/2000 (Lei de Responsabilidade Fiscal) e a Lei de $n^{\circ}$ 8.429/1992 (Lei de Improbidade Administrativa), além do art. 85, V da CRFB/1988, que cuida dos crimes de responsabilidade cometidos pelo Presidente da República e demais agentes políticos.

Portanto, o princípio da moralidade administrativa busca garantir que as ações dos chefes do executivo não fujam ao que a sociedade tem como moral, legal, honesto e de boa-fé, tal qual prevê a moral comum. Embora este princípio seja de conteúdo vago, a sua violação não deve ser subestimada, fazendo-se um julgamento não apenas do prisma da moralidade, mas também focando a legalidade do ato administrativo, pois ato imoral também será ilegal.

\subsection{O princípio da eficiência}

O princípio da eficiência passou a ter previsão expressa no texto constitucional em junho de 1998, fruto da Reforma Administrativa trazida a lume pela Emenda Constitucional $n^{\circ}$ 19, compondo o caput do art. 37 da Constituição, dispondo que "a administração pública direta e indireta de qualquer dos Poderes da União, dos Estados, do Distrito Federal e dos Municípios obedecerá aos princípios de legalidade, impessoalidade, moralidade, publicidade e eficiência".

O advento da inserção do princípio da eficiência ao caput do art. 37 da CRFB/1988 não significou que a sua observância se tornou obrigatória somente a partir do ano de 1998, sempre foi dever do Administrador Público gerir com eficiência a Máquina Pública. A inserção, embora soe como redundância, foi motivada pela necessidade de a Administração Pública obter resultados além dos que já vinha obtendo, como bem esclarece trecho da emenda de justificativa de inserção do princípio colacionada abaixo:

Como resultados esperados da reforma administrativa vale destacar a seguinte: incorporar a dimensão da eficiência na administração pública - o aparelhamento do Estado deverá se revelar apto a gerar mais benefícios à sociedade, com recursos disponíveis, em respeito ao cidadão contribuinte. ${ }^{12}$

Ora, uma vez que a mantença da Máquina Pública é feita pela população, nada mais correto que a sua gestão seja feita de forma a atender aos anseios daqueles que contribuem para o seu funcionamento e que farão uso dos serviços oferecidos pelos órgãos que compõem a Administração Pública.

12 PEREIRA JÚNIOR, Jessé Torres. Comentários à Lei das Licitações e Contratações da Administração Pública. $5^{\text {a }}$ ed. Rio de Janeiro: Renovar, 2002. p. 198. 
A EDUCAÇÃO PARA O TRÂNSITO COMO FERRAMENTA DE OBEDIÊNCIA AOS PRINCÍPIOS DA EFICIÊNCIA E DA DIGNIDADE DA PESSOA HUMANA

Paulo Rangel araújo Ferreira, Itamar da Silva Santos Filho

Conceitualmente o princípio da eficiência pode ser apresentado como "a exigência jurídica, imposta aos exercentes de função administrativa de atuação idônea, econômica e satisfatória na realização de finalidades públicas, ato ou contrato de direito público". ${ }^{13}$

Ademais, referido princípio engloba aspectos que dizem respeito tanto (I) à forma que o ente público atuará, ou seja, espera-se o melhor desempenho possível de suas atribuições, como consequência, os melhores resultados; e (II), quanto à forma de se organizar, deve ser o mais racional possível, no intuito de alcançar melhores resultados na prestação dos serviços públicos. $^{14}$

Enfim, embora alguns doutrinadores como Marinela ${ }^{15}$ e Mello ${ }^{16}$ considerem a inserção do princípio da eficiência ao texto constitucional como um mero adorno de difícil fiscalização, não se pode esquecer que a intenção do legislador constituinte ao fazê-lo foi nobre: fazer com que o povo usufruísse a contento das altas contribuições que fazem para manter a Máquina Pública funcionando. Por este motivo, se torna latente a necessidade de fiscalização por meio do Poder Judiciário e dos cidadãos, buscando dar maior fluidez e obediência a este princípio basilar da Administração Pública.

\subsection{O princípio da dignidade da pessoa humana}

O Estado Democrático de Direito se configura pela persecução do bem-estar social, impossível de se desvincular do respeito aos direitos fundamentais, da dignidade da pessoa humana e da busca pela paz perpétua nos moldes kantianos. Esta é a essência da expressão “Estado Democrático de Direito”, que está consolidada no preâmbulo da Constituição da República Federativa do Brasil de 1988.

É cediço em todas as doutrinas, consolidado em todas as legislações e pacificado em todo o mundo a importância da obediência ao referido princípio em todos os ramos do Direito, a começar pela Constituição de 1988 que cita-o como fundamento da República Federativa do Brasil, ao lado da soberania e da cidadania (art. $1^{\circ}$ ).

\footnotetext{
${ }^{13}$ AMARAL, Antônio Carlos Cintra do. 0 princípio da eficiência no direito administrativo. Revista Diálogo Jurídico, Salvador, CAJ - Centro de Atualização Jurídica, $\mathrm{n}^{\circ}$. 14, junho-agosto, 2002. Disponível em: <http:/ / direitopublico.com.br/pdf_14/DIALOGO-JURIDICO-14-JUNHO-AGOSTO-2002-ANTONIO-CARLOSCINTRA-AMARAL.pdf> Acesso em: 27 out. 2014.

${ }_{14}^{14}$ DI PIETRO, Maria Sylvia Zanella. Direito Administrativo. $27^{\text {a }}$ ed. São Paulo: Atlas, 2014. p. 83-84.

${ }^{15}$ MARINELA, op. cit., p. 44.

${ }^{16}$ MELLO, op. cit., p. 122.
} 
A EDUCAÇÃO PARA O TRÂNSITO COMO FERRAMENTA DE OBEDIÊNCIA AOS PRINCÍPIOS DA EFICIÊNCIA E DA DIGNIDADE DA PESSOA HUMANA

Paulo Rangel araújo Ferreira, Itamar da Silva Santos Filho

Princípio fundamental e núcleo do ordenamento jurídico pátrio, o princípio em comento tem o condão de assegurar que, no centro de todo direito estará o homem, fundamento e fim de toda relação jurídica. Assim, logo em seu $1^{\circ}$ artigo, a Carta Magna trouxe assegurado este princípio como preceito para efetivação do Estado Democrático de Direito, dispondo que a República Federativa do Brasil, formada pela união indissolúvel dos Estados e Municípios e do Distrito Federal, constitui-se em Estado Democrático de Direito e tem como fundamentos: a soberania, a cidadania, a dignidade da pessoa humana.

Além do supracitado artigo, diversos são os exemplos da exigência de respeito à dignidade da pessoa humana presentes no texto constitucional: o artigo 226, $\$ 7^{\circ}$ prevê que $o$ planejamento familiar seja fundado nos princípios da dignidade da pessoa humana e da paternidade responsável; o caput do artigo 230 assegura à pessoa idosa o cuidado por meio da família e do Estado, de maneira a garantir a sua dignidade; e, o artigo 227, caput, prevê que é dever da família e do Estado assegurar à criança e ao adolescente o direito à dignidade, dentre outros exemplos espalhados por toda a legislação brasileira.

A Constituição de 1988 colocou a dignidade da pessoa humana como um dos fundamentos do Estado brasileiro e assumiu o compromisso com a preservação de um dos valores mais sagrados do homem, qual seja, a sua dignidade. Motivo pelo qual, toda ação dos chefes do Poder Executivo deve ser no sentido de salvaguardar este princípio e promover a sua efetivação.

Mister se faz acrescentar que o princípio da dignidade da pessoa humana não objetiva dar ao ser humano sua dignidade, pois ele já a possui; o que se objetiva, primeiramente, é que essa dignidade seja protegida; secundariamente, que haja uma prestação. Logo, em sua função protetiva refere-se a normas que outorgam direitos subjetivos negativos (não violação da dignidade), e em função prestacional, o princípio impõe condutas positivas no sentido de proteger e promover a dignidade do ser humano. ${ }^{17}$

Embora não se possa atribuir um conceito objetivo e invariável, a dignidade da pessoa humana é descrita analiticamente por Silva como “[...] um valor supremo que atrai conteúdo de todos os direitos fundamentais do homem, desde o direito à vida; Concebido como referência constitucional unificadora de todos os direitos fundamentais [...]". ${ }^{18}$

\footnotetext{
17 SARLET, Ingo Wolfgang. A eficácia dos direitos fundamentais. Porto Alegre: Livraria do Advogado, 1998. p. 71.

${ }^{18}$ SILVA, José Afonso da. Curso de Direito Constitucional Positivo. 25a. ed. São Paulo: Malheiros, 2005. p. 95.
} 
A EDUCAÇÃO PARA O TRÂNSITO COMO FERRAMENTA DE OBEDIÊNCIA AOS PRINCÍPIOS DA EFICIÊNCIA E DA DIGNIDADE DA PESSOA HUMANA

Paulo Rangel araújo Ferreira, Itamar da Silva Santos Filho

Portanto, qualquer ato que vá contra um princípio também fere todo o ordenamento jurídico. Por sua vez, o princípio da dignidade da pessoa humana é possuidor de força universal, sendo a sua desobediência, inclusive, motivo de submissão ao direito internacional, seja por falta estatal ou desobediência de normas positivadas.

\section{DAS BASES LEGAIS DA EDUCAÇÃO PARA O TRÂNSITO}

O sistema educacional brasileiro é disciplinado pela CRFB, PNE, LDB, PCN, dentre outras leis e manuais esparsos.

A educação básica brasileira está dividida em 3 etapas e, conforme preceitua a LDB, deve acompanhar crianças e jovens dos 0 aos 17 anos. Em sua primeira etapa refere-se à alfabetização (pré-escola/creche), que é ofertada para as idades de 0 aos 5 anos; a segunda etapa, referente ao ensino fundamental ( $1^{\circ}$ ao $9^{\circ}$ ano), corresponde às idades de 6 aos 14 anos; e a terceira etapa referente ao Ensino Médio $\left(1^{\mathrm{a}}\right.$ à $3^{\mathrm{a}}$ série, ou $1^{\mathrm{a}}$ à $4^{\mathrm{a}}$, no caso do ensino médio profissionalizante), corresponde às idades de 15 aos 17 anos, conforme fluxograma abaixo:

Tabela 1 - Fluxograma Educação Básica Brasileira

\begin{tabular}{|c|c|c|c|c|c|}
\hline \multicolumn{6}{|c|}{ EDUCAÇÃO BÁSICA BRASILEIRA } \\
\hline Idade & Nível & & Etapa & Duração & Objetivo \\
\hline 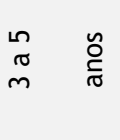 & & \multirow{2}{*}{\multicolumn{2}{|c|}{ 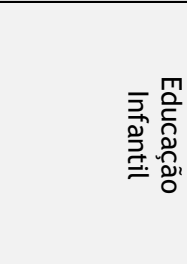 }} & \multirow{2}{*}{ 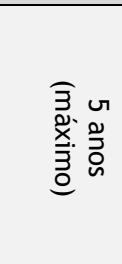 } & \multirow[t]{2}{*}{$\begin{array}{l}\text { O desenvolvimento físico, psicológico, intelectual e social da criança. } \\
\text { As atividades realizadas são um complemento à ação das famílias e das } \\
\text { comunidades. Crianças de zero a três anos podem frequentar as creches } \\
\text { ou instituições equivalentes. No caso de crianças entre quatro e cinco } \\
\text { anos, o ensino é realizado em pré-escolas. }\end{array}$} \\
\hline $\begin{array}{ll}N & \text { ก } \\
0 & \stackrel{\sigma}{\sigma}\end{array}$ & Creche & & & & \\
\hline 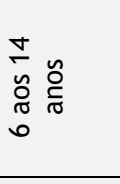 & Fundamental & 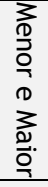 & 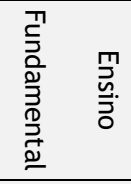 & 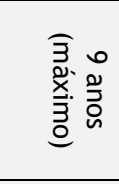 & $\begin{array}{l}\text { Em sua conclusão, o estudante deve dominar a leitura, a escrita e o } \\
\text { cálculo. Outro objetivo desta etapa é desenvolver a capacidade de } \\
\text { compreender o ambiente natural e social, o sistema político, a } \\
\text { tecnologia, as artes e os valores básicos da sociedade e da família. }\end{array}$ \\
\hline 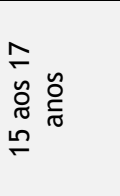 & $\begin{array}{c}\text { Médio/ } \\
\text { Profissionalizante }\end{array}$ & & 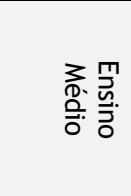 & 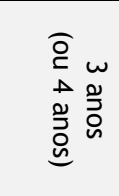 & $\begin{array}{l}\text { Nesse período, são aprofundados os conhecimentos adquiridos no ensino } \\
\text { fundamental, buscando articular o conteúdo com a preparação básica } \\
\text { para o trabalho e a cidadania. Outra função do ensino médio é propiciar } \\
\text { a formação ética, o desenvolvimento da autonomia intelectual e do } \\
\text { pensamento crítico e a compreensão dos fundamentos científico- } \\
\text { tecnológicos dos processos produtivos. }\end{array}$ \\
\hline
\end{tabular}

Fonte: Portal Brasil. ${ }^{19}$

${ }^{19}$ BRASIL. Saiba como é a divisão do sistema de educação brasileiro. In: Portal Brasil. Disponível em: <http://www.brasil.gov.br/educacao/2014/05/saiba-como-e-a-divisao-do-sistema-de-educacaobrasileiro/view> Acesso: 24 out. 2014. 
A EDUCAÇÃO PARA O TRÂNSITO COMO FERRAMENTA DE OBEDIÊNCIA AOS PRINCÍPIOS DA EFICIÊNCIA E DA DIGNIDADE DA PESSOA HUMANA

Paulo Rangel araújo Ferreira, Itamar da Silva Santos Filho

A educação básica é de oferta e matrícula obrigatória dos 4 aos 17 anos de idade, aos municípios cabendo a oferta do ensino fundamental e da educação infantil, prioritariamente; e aos estados e ao Distrito Federal a oferta do ensino fundamental e médio, conforme capítulo III, Seção I (artigos 205 a 214) da Constituição Federal de 1988.

\subsection{Da Constituição Federal de 1988}

Todas as legislações atinentes à educação têm o mesmo objetivo quando o assunto é a formação do cidadão: formá-lo intelectual, social e humanamente, no sentido de fazer do homem ser útil à sociedade, conhecedor de sua história, de seu papel no lugar em que está inserido, praticando o que aprendeu, ou seja, visa-se o pleno desenvolvimento da pessoa, seu preparo para o exercício da cidadania e sua qualificação para o trabalho, é o que versa o art. 205 da Constituição de 1988.

Não obstante, cabe ao Estado a garantia do acesso à educação, conforme preceitua a Carta Magna (art. 208), sendo competência da União, dos Estados, do Distrito Federal e dos Municípios organizarem em regime de colaboração seus sistemas de ensino (art. 211), conforme descrito em tópico anterior.

Insta registrar que de igual modo está disciplinada a oferta da Educação para o Trânsito no texto constitucional, sendo os supracitados entes competentes para estabelecer e implantar política de educação para a segurança do trânsito (art. 23, XII).

Além de todas as supracitadas normas e, como núcleo-guia do que ora defende o presente trabalho, pode-se citar como principal fundamento para a oferta da Educação para o Trânsito, o direito fundamental de ir e vir em segurança, que faz parte do rol de direitos e garantias fundamentais, os quais estão inseridos no art. $5^{\circ}$ da Constituição de 1988 , ao lado de diversos outros direitos sagrados para o homem.

Neste sentido, Honorato ${ }^{20}$ endossa que a maior necessidade hoje é a de “[...] reconhecer o Trânsito Seguro como um Direito Humano e Fundamental, a ser promovido pelo Estado, declarando não apenas a Liberdade de Circulação como espécie de direito individual, e sim o Trânsito Seguro como um conjunto de deveres coletivos [...]”.

Além das normas há muito consolidadas no texto constitucional, recentemente a EC $\mathrm{n}^{\circ}$ 82, publicada no DOU em 17 de julho de 2014 veio reafirmar todas as demais normas supracitadas aqui. 0 texto que incluiu o $\$ 10$ ao art. 144 da Constituição versa que a segurança

${ }^{20}$ HONORATO, Cássio Mattos. Trânsito Seguro: direito fundamental de segunda dimensão. RT 911, ano 100, p. 107-169, set. 2011. 
A EDUCAÇÃO PARA O TRÂNSITO COMO FERRAMENTA DE OBEDIÊNCIA AOS PRINCÍPIOS DA EFICIÊNCIA E DA DIGNIDADE DA PESSOA HUMANA

Paulo Rangel araújo Ferreira, Itamar da Silva Santos Filho

viária, exercida para a preservação da ordem pública e da incolumidade das pessoas e do seu patrimônio nas vias públicas (I) compreende a educação, engenharia e fiscalização de trânsito, além de outras atividades previstas em lei, que assegurem ao cidadão o direito à mobilidade urbana eficiente.

Nota-se que o texto do $\$ 10$ acrescentado ao art. 144 ratifica a importância da Educação para o Trânsito como garantia da segurança viária e do bem-estar individual e coletivo, conforme já previa outras normas do ordenamento jurídico brasileiro, além de estar de acordo com a proposta da Organização das Nações Unidas (ONU) que decretou o período de 2011 a 2020 como a Década de Ação Pelo Trânsito Seguro, na qual "governos de todo o mundo se comprometem a tomar novas medidas para prevenir os acidentes no trânsito"21.

\subsection{Do plano nacional de educação (PNE) e do plano nacional de educação em direitos humanos (PNEDH)}

O PNE tem a função de elaborar diretrizes, metas e estratégias para a melhoria da educação básica brasileira para o período dos dez anos subsequentes. Fruto do compromisso do Estado com a preservação dos direitos humanos, o PNEDH, por sua vez, tem a função de promover a educação em direitos humanos e, para isto, também, elaborou-se, diretrizes, metas e estratégias.

O PNE tem força de lei e é de elaboração obrigatória, tanto a nível federal, quanto estadual e municipal, tendo estados e municípios o prazo de 1 (um) ano, contado a partir da data de publicação da lei que deu origem ao PNE, para elaborarem seus próprios planos ou adaptar o texto do PNE às realidades locais.

Destarte, o Plano Estadual e Municipal sempre estará subordinado às diretrizes e metas do Plano Nacional, embora possa acrescer a ele conteúdos, metas e estratégias que mais se adequarem à região, mas que não extrapolem as competências ou firam o PNE em sua essencialidade, é o que prevê o art. $8^{\circ}$ do PNE vigente.

A Lei $n^{\circ} 13.005$, de 25 de junho de 2014, que aprovou o PNE com vigência de dez anos (2014-2024), apresenta diretrizes muito condizentes com a ideia de efetivação dos direitos fundamentais, ademais, são diretrizes que devem ser cumpridas junto à oferta da educação básica do cidadão e, dentre elas, conforme o art. $2^{\circ}$ da citada lei, estão "a formação para o

${ }^{21}$ ONUBR. Organização das Naçães Unidas no Brasil. Década de ação pelo trânsito seguro 2011-2020 é lançada oficialmente hoje (11) em todo o mundo. Disponível em: <http://www.onu.org.br/decada-deacao-pelo-transito-seguro-2011-2020-e-lancada-oficialmente-hoje-11-em-todo-o-mundo/> Acesso: 08 nov. 2014. 
A EDUCAÇÃO PARA O TRÂNSITO COMO FERRAMENTA DE OBEDIÊNCIA AOS PRINCÍPIOS DA EFICIÊNCIA E DA DIGNIDADE DA PESSOA HUMANA

Paulo Rangel araújo Ferreira, Itamar da Silva Santos Filho

trabalho e para a cidadania, com ênfase nos valores morais e éticos em que se fundamenta a sociedade", a "promoção humanística, científica, cultural e tecnológica do País" e a "promoção dos princípios do respeito aos direitos humanos, à diversidade e à sustentabilidade socioambiental" (incisos V, VII e X, respectivamente).

As supracitadas legislações atinentes à educação básica brasileira deixam claro que, mesmo em sede de ensino fundamental e médio, o ensino não deve estar desvinculado da ideia de promoção humanística e dos direitos fundamentais. Para a discussão protelada pelo presente trabalho, isto se faz de grande valia, uma vez que, a segurança no trânsito é direito fundamental de segunda dimensão e, tanto o PNE quanto o PNEDH endossam a obrigatoriedade de a escola incluir em seus currículos assuntos que promovam o respeito aos direitos humanos e sociais, se não, vejamos alguns princípios presentes no $\mathrm{PNEDH}^{22}$ :

a) a educação deve ter a função de desenvolver uma cultura de direitos humanos em todos os espaços sociais;

b) a escola, como espaço privilegiado para a construção e consolidação da cultura de direitos humanos, deve assegurar que os objetivos e as práticas a serem adotados sejam coerentes com os valores e princípios da educação em direitos humanos;

c) a educação em direitos humanos, por seu caráter coletivo, democrático e participativo, deve ocorrer em espaços marcados pelo entendimento mútuo, respeito e responsabilidade;

(...)

f) a prática escolar deve ser orientada para a educação em direitos humanos, assegurando o seu caráter transversal e a relação dialógica entre os diversos atores sociais.

A transversalidade a que se refere o PNEDH tem a ver com a inclusão de temas incomuns ao currículo escolar no dia a dia do trabalho feito em sala de aula. Esta previsão visa envolver os alunos com os acontecimentos do cotidiano, os assuntos que eles veem todos os dias na internet e na TV, mas que são colocados para escanteio pela família e/ou escola, dentre estes assuntos, estão os direitos humanos e a segurança no trânsito.

A posteriori muito tem em comum o PNE e o PNEDH, pois ambos os planos tratam da educação e têm a promoção humanística e o respeito aos direitos fundamentais como foco e, sendo a segurança no trânsito direito fundamental de segunda dimensão, torna-se essencial a análise conjunta, não apenas dos dois planos, como também do que prescreve o CTB, no tocante à Educação para o Trânsito, os PCN, a LDB, assim como o texto constitucional no que se refere às competências de cada ente federado para o trânsito.

${ }^{22}$ BRASIL. Comitê Nacional de Educação em Direitos Humanos. Plano nacional de educação em direitos humanos. Brasília: Secretaria Especial dos Direitos Humanos, 2007. p. 23. 
A EDUCAÇÃO PARA O TRÂNSITO COMO FERRAMENTA DE OBEDIÊNCIA AOS PRINCÍPIOS DA EFICIÊNCIA E DA DIGNIDADE DA PESSOA HUMANA

Paulo Rangel araújo Ferreira, Itamar da Silva Santos Filho

A guisa de conclusão, é essencial que se diga que a escola é a principal parceira na efetivação de qualquer direito de caráter fundamental, e que o ensino é a ferramenta mais valiosa para o conhecimento e a promoção destes direitos.

\subsection{Do código de trânsito brasileiro (CTB)}

A Educação para o Trânsito é tema de todo um capítulo do CTB, Lei $n^{\circ} 9.503$ de 23 de setembro de 1997. São onze artigos dotados de um conteúdo que não deveria ser negligenciado, posto que tal ato custa a vida de dezenas de milhares de brasileiros todos os anos, conforme será demonstrado no capítulo 3 ("Do Trânsito em Números”).

No que se refere à Educação para o Trânsito, o CTB é o principal embasamento para o presente trabalho, uma vez que, é a ele, principalmente, que se pretende dar efetividade; é o que está previsto em seu capítulo VI (“Da Educação Para o Trânsito”) que motivou a tese ora defendida pelos autores.

Principal ferramenta na busca pela segurança no trânsito, o CTB é apontado como uma das leis de trânsito mais modernas do mundo ${ }^{23} \mathrm{e}$, logo em seu $1^{\circ}$ artigo, $\S 2^{\circ}$, dispõe que “o trânsito, em condições seguras, é um direito de todos e dever dos órgãos e entidades componentes do Sistema Nacional de Trânsito, a estes cabendo, no âmbito das respectivas competências, adotar as medidas destinadas a assegurar esse direito".

Logo, não é uma faculdade dos gestores públicos proporcionarem segurança no trânsito, é um direito de todo cidadão, que deve usufruir de um sistema de trânsito seguro e salvaguardado como bem coletivo que consome recursos para oferecer benefícios para o cidadão contribuinte. ${ }^{24}$

A Educação para o Trânsito, por sua vez, não é tema novo nas leis de trânsito brasileiras que já datam mais de 100 anos de existência ${ }^{25}$, desde as vanguardistas Posturas de Câmara Municipal da Corte Sobre Carros, Seges e Outros Veículos de Transporte ${ }^{26}$ até chegar ao

\footnotetext{
${ }^{23}$ NEVES, Luiz Octávio Rocha Miranda C. O novo código de trânsito sofre com a impunidade. In: Revista Visão Jurídica, № 81 - 2013. São Paulo: Editora Escala, 2013. p. 36.

${ }^{24}$ MANHEIN, 1979 apud SOUZA, J. L. de. Sobre a forma e o conteúdo da educação para o trânsito no ensino fundamental. 2010. 124 f. Tese (Doutorado) - Escola de Engenharia de São Carlos - Universidade de São Paulo, São Carlos, 2010. p.6.

${ }^{25}$ BRASIL. Departamento Nacional de Trânsito. 100 anos de Legislação de Trânsito no Brasil: 1910 -2010 / Ministério das Cidades, Departamento Nacional de Trânsito, Conselho Nacional de Trânsito. - Brasília: Ministério das Cidades, 2010.

${ }^{26}$ ARAÚJO, Lulyver Modesto. Poder de polícia administrativa de trânsito. São Paulo: Letras Jurídicas, 2010. p. 64.
} 
A EDUCAÇÃO PARA O TRÂNSITO COMO FERRAMENTA DE OBEDIÊNCIA AOS PRINCÍPIOS DA EFICIÊNCIA E DA DIGNIDADE DA PESSOA HUMANA

Paulo Rangel araújo Ferreira, Itamar da Silva Santos Filho

moderno CTB, outras normas tornaram cediço no ordenamento jurídico brasileiro a necessidade da Educação para o Trânsito, vejamos o exemplo do Código de Trânsito de 1966, que dispunha:

Art. $4^{\circ}$. O Conselho Nacional de Trânsito, com sede no Distrito Federal, subordinado diretamente ao Ministério da Justiça e Negócios Interiores, é o órgão máximo normativo da coordenação da política e do sistema nacional de trânsito e compor-se-á dos seguintes membros, tecnicamente capacitados em assuntos de trânsito:

(...)

f ) um representante do Ministério da Educação e Cultura;

(...)

Art. $5^{\circ}$. Compete ao Conselho Nacional de Trânsito, além do que dispõem outros artigos deste Código:

(...)

X - Promover e coordenar campanhas educativas de trânsito;

(...)

Art. 125. O Ministério da educação e Cultura promoverá a divulgação de noções de trânsito nas escolas primárias e médias do País, segundo programa estabelecido de acordo com o Conselho Nacional de Trânsito.

A exemplo do seu antecessor, mas de maneira analítica e explícita, o CTB criou não só todo um capítulo dedicado ao tema da Educação para o Trânsito (artigos. 74 a 79), como distribuiu as competências e determinou a forma que ela se daria, frisando que a mesma deveria ser ofertada desde as séries iniciais da educação básica e, não na forma de disciplinas, mas de conteúdos programáticos. Vejamos o que versa o art. 76 do CTB acerca do tema:

Art. 76. A educação para o trânsito será promovida na pré-escola e nas escolas de $1^{\circ}, 2^{\circ}$ e $3^{\circ}$ graus, por meio de planejamento e ações coordenadas entre os órgãos e entidades do Sistema Nacional de Trânsito e de Educação, da União, dos Estados, do Distrito Federal e dos Municípios, nas respectivas áreas de atuação.

Parágrafo único. Para a finalidade prevista neste artigo, o Ministério da Educação e do Desporto, mediante proposta do CONTRAN e do Conselho de Reitores das Universidades Brasileiras, diretamente ou mediante convênio, promoverá:

I - a adoção, em todos os níveis de ensino, de um currículo interdisciplinar com conteúdo programático sobre segurança de trânsito;

II - a adoção de conteúdos relativos à educação para o trânsito nas escolas de formação para o magistério e o treinamento de professores e multiplicadores;

III - a criação de corpos técnicos interprofissionais para levantamento e análise de dados estatísticos relativos ao trânsito;

IV - a elaboração de planos de redução de acidentes de trânsito junto aos núcleos interdisciplinares universitários de trânsito, com vistas à integração universidades-sociedade na área de trânsito.

Como ficou claro pelas supracitadas normas, não existe obstáculo à efetivação da Educação para o Trânsito além da falta de proposta do Conselho Nacional de Trânsito (CONTRAN) 
A EDUCAÇÃO PARA O TRÂNSITO COMO FERRAMENTA DE OBEDIÊNCIA AOS PRINCÍPIOS DA EFICIÊNCIA E DA DIGNIDADE DA PESSOA HUMANA

Paulo Rangel araújo Ferreira, Itamar da Silva Santos Filho

para tanto. Frisa-se que o ordenamento jurídico brasileiro proporciona mais de uma possibilidade de efetivação desta benesse, que poderia levar ao mesmo resultado ora presumido, ou seja, ainda que haja a ausência de manifestação do CONTRAN no sentido de efetivar a Educação para o Trânsito, existe previsão de normas educacionais que possibilitam o uso da transversalidade para trabalhar o tema 'trânsito' de forma contextualizada com as disciplinas comuns a todas as séries da educação básica brasileira (ensino infantil, fundamental e médio), é o caso da Lei de Diretrizes e Bases da Educação Nacional (LBDEN) e dos Parâmetros Curriculares Nacionais (PCN), próximas normas a serem apresentadas.

\subsection{Da lei de diretrizes e bases (LDB) e dos parâmetros curriculares nacionais (PCN)}

A LDB e os PCN são importantes ferramentas no tocante à efetivação da Educação para o Trânsito, uma vez que, todo e qualquer assunto que altere o currículo escolar da educação básica não poderá ser feita sem estar de acordo com o que prevê a lei maior da educação brasileira, descrito nos PCN e/ou previsto como meta do PNE para os próximos dez anos.

A LDB, Lei 9.394 de 20 de dezembro de 1996, a exemplo de todas as outras legislações expostas até aqui, não deixou de prever a educação como meio de resolver os problemas da sociedade, fazendo da escola elemento transformador da realidade, como bem expressa o seu artigo $1^{\circ}$ versando que "a educação abrange os processos formativos que se desenvolvem na vida familiar, na convivência humana, no trabalho, nas instituições de ensino e pesquisa, nos movimentos sociais e organizações da sociedade civil e nas manifestações culturais". ${ }^{27}$

Para que os objetivos supracitados sejam alcançados a LDB obriga que as instituições de ensino públicas e privadas tenham, além de uma base comum de conteúdos distribuídos entre todas as séries da Educação Básica, ensino diversificado que envolva tanto assuntos relacionados ao meio em que os educandos estejam inseridos como relativos à cultura, política e atinentes às características de cada idade/série, como versa o art. 26 da $\mathrm{LDB}^{28}$, in verbis:

Art. 26. Os currículos da educação infantil, do ensino fundamental e do ensino médio devem ter base nacional comum, a ser complementada, em cada sistema de ensino e em cada estabelecimento escolar, por uma parte diversificada, exigida pelas características regionais e locais da sociedade, da cultura, da economia e dos educandos.

\footnotetext{
27 BRASIL. LDB: Lei de diretrizes e bases da educação nacional: Lei $n^{\circ}$ 9.394, de 20 de dezembro de 1996, que estabelece as diretrizes e bases da educação nacional. - 9a ed. - Brasília: Câmara dos Deputados, Edições Câmara, 2014. p. 9.

${ }^{28}$ BRASIL, op. cit., p. 19-20.
} 
A EDUCAÇ̃̃O PARA O TRÂNSITO COMO FERRAMENTA DE OBEDIÊNCIA AOS PRINCÍPIOS DA EFICIÊNCIA E DA DIGNIDADE DA PESSOA HUMANA

Paulo Rangel araújo Ferreira, Itamar da Silva Santos Filho

$\S 1^{\circ}$ Os currículos a que se refere o caput devem abranger, obrigatoriamente, o estudo da língua portuguesa e da matemática, o conhecimento do mundo físico e natural e da realidade social e política, especialmente do Brasil.

A previsão do art. 26 da LDB foi parcialmente efetivada quando, em meados do ano de 1997, pari passu à entrada em vigor do CTB, foram inseridos no currículo escolar da educação básica a transversalidade, sendo usado como critério para a escolha dos temas que deveriam ser trabalhados de maneira transversal em sala de aula a (I) urgência social, a (II) abrangência nacional, a (III) possibilidade de ensino-aprendizagem no ensino fundamental e (IV) a possibilidade de favorecer a compreensão da realidade e a participação social. ${ }^{29}$

Os assuntos escolhidos para figurar no rol dos Temas Transversais para a Educação foram: Ética; Pluralidade Cultural; Meio Ambiente; Saúde; Orientação Sexual, além da possibilidade de as escolas inserirem os ditos Temas Locais. ${ }^{30} \mathrm{O}$ trânsito, ao arrepio da lei, não foi inserido sob a justificativa de não se tratar de tema de abrangência nacional, podendo ser inserido apenas como tema local. ${ }^{31}$

Por fim, vale acrescentar posicionamento de Souza, para quem os temas transversais têm o condão de fazer com que o ensino proporcione aos educandos uma visão completa da realidade, além do desenvolvimento de capacidades cognitivas e de comportamentos reflexos positivos no tocante às mais diversas situações, o que tornaria claramente possível o trabalho do trânsito como tema transversal para a educação. ${ }^{32}$

\section{DO TRÂNSITO EM NÚMEROS}

\subsection{Das estatísticas mundiais}

Segundo Relatório Anual do International Road Traffic and Accident Database (IRTAD), órgão da Organização para a Cooperação e Desenvolvimento Econômico (OECD), no decorrer de pouco mais de uma década (2000-2011) o número de mortes causadas por Acidentes de Transportes Terrestre (ATT), dentre seus países membros, registrou queda no número de acidentes por categoria de até $68 \%$, como é o caso dos motociclistas na Noruega; comparativamente, no Brasil, que não é um país membro da $\mathrm{OECD}$, o número de ATT envolvendo

\footnotetext{
29 BRASIL. Secretaria de Educação Fundamental. Parâmetros curriculares nacionais: apresentação dos temas transversais, ética / Secretaria de Educação Fundamental. - Brasília: MEC/SEF, 1997. p. 25-26.

30 BRASIL, op. cit., p. 45.

31 BRASIL. Departamento Nacional de Trânsito (DENATRAN). Educação de trânsito no ensino regular. Disponível: <http://www.denatran.gov.br/download/unidade\%202.pdf> Acesso: 20 abr. 2015.

${ }^{32}$ SOUZA, op. cit., p.47.
} 
A EDUCAÇÃO PARA O TRÂNSITO COMO FERRAMENTA DE OBEDIÊNCIA AOS PRINCÍPIOS DA EFICIÊNCIA E DA DIGNIDADE DA PESSOA HUMANA

Paulo Rangel araújo Ferreira, Itamar da Silva Santos Filho

a categoria motociclistas registrou um aumento de $275 \%$ no mesmo período descrito pelo Relatório ${ }^{33}$.

A tabela abaixo mostra em detalhes a evolução e/ou declínio do número de acidentes por categoria dos países que compõem a OECD entre os anos de 2000 e 2011 comparados ao Brasil:

Tabela 2 - Evolução (\%) do número de mortes em Acidentes de Trânsito (AT) segundo classes de usuário

\begin{tabular}{|c|c|c|c|c|c|}
\hline PAÍS & BICICLETA & MOTOCICLETA & AUTOMÓVEL & PEDESTRE & TOTAL \\
\hline Alemanha & $-40 \%$ & $-25 \%$ & $-55 \%$ & $-38 \%$ & $-47 \%$ \\
\hline Austrália & $10 \%$ & $6 \%$ & $-34 \%$ & $-36 \%$ & $-30 \%$ \\
\hline Áustria & $-32 \%$ & $-46 \%$ & $-47 \%$ & $-38 \%$ & $-46 \%$ \\
\hline Bélgica & $-49 \%$ & $8 \%$ & $-51 \%$ & $-22 \%$ & $-41 \%$ \\
\hline Canadá & $25 \%$ & $12 \%$ & $-23 \%$ & $-21 \%$ & $-23 \%$ \\
\hline Coreia & $-14 \%$ & $-50 \%$ & $-58 \%$ & $-46 \%$ & $-49 \%$ \\
\hline Dinamarca & $-48 \%$ & $-48 \%$ & $-54 \%$ & $-67 \%$ & $-56 \%$ \\
\hline Eslovênia & $-46 \%$ & $-25 \%$ & $-62 \%$ & $-65 \%$ & $-55 \%$ \\
\hline Espanha & $-42 \%$ & $-11 \%$ & $-70 \%$ & $-58 \%$ & $-64 \%$ \\
\hline Estados Unidos & $-2 \%$ & $59 \%$ & $-42 \%$ & $-7 \%$ & $-23 \%$ \\
\hline Finlândia & $-64 \%$ & $100 \%$ & $-23 \%$ & $-34 \%$ & $-26 \%$ \\
\hline França & $-48 \%$ & $-20 \%$ & $-61 \%$ & $-39 \%$ & $-51 \%$ \\
\hline Grécia & $-41 \%$ & $-25 \%$ & $-47 \%$ & $-41 \%$ & $-44 \%$ \\
\hline Holanda & $-14 \%$ & $-52 \%$ & $-57 \%$ & $-35 \%$ & $-43 \%$ \\
\hline Hungria & $-53 \%$ & $0 \%$ & $-46 \%$ & $-64 \%$ & $-47 \%$ \\
\hline Irlanda & $-10 \%$ & $-54 \%$ & $-63 \%$ & $-45 \%$ & $-55 \%$ \\
\hline Israel & $-20 \%$ & $10 \%$ & $-24 \%$ & $-32 \%$ & $-25 \%$ \\
\hline Itália & $-30 \%$ & $20 \%$ & $-57 \%$ & $-40 \%$ & $-45 \%$ \\
\hline Japão & $-32 \%$ & $-36 \%$ & $-63 \%$ & $-33 \%$ & $-47 \%$ \\
\hline Noruega & $-15 \%$ & $-68 \%$ & $-56 \%$ & $-64 \%$ & $-51 \%$ \\
\hline Nova Zelândia & $-53 \%$ & $6 \%$ & $-44 \%$ & $-11 \%$ & $-39 \%$ \\
\hline Polônia & $-55 \%$ & $64 \%$ & $-30 \%$ & $-38 \%$ & $-33 \%$ \\
\hline Portugal & $-29 \%$ & $-50 \%$ & $-59 \%$ & $-53 \%$ & $-53 \%$ \\
\hline Reino Unido & $-17 \%$ & $-40 \%$ & $-49 \%$ & $-47 \%$ & $-46 \%$ \\
\hline República Tcheca & $-58 \%$ & $-28 \%$ & $-49 \%$ & $-51 \%$ & $-48 \%$ \\
\hline Suécia & $-55 \%$ & $18 \%$ & $-60 \%$ & $-27 \%$ & $-46 \%$ \\
\hline Suíça & $-19 \%$ & $-34 \%$ & $-56 \%$ & $-47 \%$ & $-46 \%$ \\
\hline Brasil & $52 \%$ & $275 \%$ & $50 \%$ & $-13 \%$ & $49 \%$ \\
\hline
\end{tabular}

Em análise geral, vislumbra-se uma queda total no número de ATT em todos os países elencados pelo supracitado órgão no período de 2000 a 2011, comparativamente, o Brasil teve um aumento de $49 \%$ no número de ATT. Vê-se, ainda, que somente Canadá e Austrália tiveram aumento no número de ATT em uma das categorias analisadas: o primeiro aumentou $25 \%$ no número de mortes entre ciclistas e o segundo 10\%, enquanto que o Brasil, no mesmo período, houve um aumento de $52 \%$ no número de mortes desta categoria. ${ }^{35}$

\footnotetext{
${ }^{33}$ WAISELFISZ, op. cit., p. 54.

${ }^{34}$ WAISELFISZ, op. cit., p. 55.

${ }^{35}$ WAISELFISZ, op. cit., p. 54.
} 
A EDUCAÇÃO PARA O TRÂNSITO COMO FERRAMENTA DE OBEDIÊNCIA AOS PRINCÍPIOS DA EFICIÊNCIA E DA DIGNIDADE DA PESSOA HUMANA

Paulo Rangel araújo Ferreira, Itamar da Silva Santos Filho

Outros pontos da tabela que merecem destaque é a comparação do aumento do número de mortes de motociclistas no Brasil (275\%) comparado com o maior aumento dos países que compõem a OECD, qual seja, a Finlândia que teve um aumento de $100 \%$, menos da metade do aumento de óbitos desta categoria no Brasil. ${ }^{36}$

Outro fato importante é que o Brasil foi o único país em que houve aumento e não queda no número de óbitos de ocupantes de veículos, aumento este de $50 \%$ no período de 2000 a 2011. ${ }^{37}$

Dentre todas as categorias, e comparado a todos os países, o Brasil só conseguiu acompanhar os mesmos números de redução de ATT no quesito mortes de pedestres. ${ }^{38}$

Neste diapasão, questionando-se sobre o porquê de nos países ricos (a exemplo dos supracitados que compõem a OECD), mesmo com o constante aumento da frota de veículos, as taxas de óbitos são reduzidas e tendentes a decrescer, Minayo ${ }^{39}$ aduz que, nestes países, "existem investimentos concretos para que os cidadãos usufruam de um trânsito saudável: frotas mais novas, melhor treinamento de motoristas, legislação rigorosa, sinalização adequada, disciplina rígida e fiscalização no trânsito", diferentemente do que acontece no Brasil e demais países do BRIC (Brasil, Rússia, Índia, China), líderes em mortalidade por ATT. ${ }^{40}$

\subsection{Da evolução do número de acidentes no Brasil}

No período de 1980 a 2011 o SIM/MS contabilizou o total de 980.838 mortes causadas por ATT nas vias do Estado brasileiro; são cerca de 32 mil mortes por ano, mais de 80 por dia.

Até chegar ao status quo das vias públicas brasileiras, pode-se dividir o problema envolvendo os ATT no Brasil em três momentos, com base nos números apresentados pelo SIM. Primeiro, (I) do início da década de 90 até o ano de 1997 - há um significativo aumento no número de mortes; (II) de 1997 a 2000 - após a publicação do Novo Código de Trânsito, houve um declínio no número de mortes, motivado pelo rigor da nova legislação e, também, pelas diversas

\footnotetext{
${ }^{36}$ WAISELFISZ, op. cit., p. 54.

${ }^{37}$ WAISELFISZ, op. cit., p. 54.

${ }^{38}$ WAISELFISZ, op. cit., p. 54.

${ }^{39}$ MINAYO, Maria Cecília de S. Morre menos quem morre no trânsito?. Revista Ciência \& Saúde Coletiva, Rio de Janeiro, vol. 17, set. 2012. p. 2237-2238.

40 MOYSÉS, Samuel J. Determinação sociocultural dos acidentes de transporte terrestre (ATT). Revista Ciência \& Saúde Coletiva, Rio de Janeiro, vol. 17, set. 2012. p. 2241-2243.
} 
A EDUCAÇÃO PARA O TRÂNSITO COMO FERRAMENTA DE OBEDIÊNCIA AOS PRINCÍPIOS DA EFICIÊNCIA E DA DIGNIDADE DA PESSOA HUMANA

Paulo Rangel araújo Ferreira, Itamar da Silva Santos Filho

campanhas; (III) a partir de 2000 - os números crescem contínua e sistematicamente, com perspectivas de crescimento anuais superiores a $3,7 \%$ ao ano, em média. ${ }^{41}$

Tabela 3 - Número de mortes em AT no Brasil nos anos de 1980 a 2011.

\begin{tabular}{|l|c|c|c|c|c|}
\hline ANO & NÚMERO & ANO & NÚMERO & ANO & NÚMERO \\
\hline 1980 & 20.203 & 1991 & 28.328 & 2002 & 32.753 \\
\hline 1981 & 19.487 & 1992 & 27.122 & 2003 & 33.139 \\
\hline 1982 & 21.128 & 1993 & 27.790 & 2004 & 35.105 \\
\hline 1983 & 20.536 & 1994 & 29.445 & 2005 & 35.994 \\
\hline 1984 & 22.404 & 1995 & 33.047 & 2006 & 36.367 \\
\hline 1985 & 24.840 & 1996 & 35.281 & 2007 & 37.407 \\
\hline 1986 & 30.070 & 1997 & 35.620 & 2008 & 38.273 \\
\hline 1987 & 28.048 & 1998 & 30.890 & 2009 & 37.594 \\
\hline 1988 & 28.426 & 1999 & 29.569 & 2010 & 40.989 \\
\hline 1989 & 29.255 & 2000 & 28.995 & 2011 & 43.256 \\
\hline 1990 & 28.953 & 2001 & 30.524 & & 980.838 \\
\hline
\end{tabular}

Fonte: Mapa da Violência no Trânsito - 2013. ${ }^{4 L}$

Pela tabela apresentada acima, pode-se constatar que nos últimos 11 anos apresentados, o número de mortes por AT subiu de 28.995 para 43.256, um aumento de 14.261 mortes, o que representa um percentual de aumento de mais de $49 \%$ em pouco mais de 10 anos.

Diversos são os motivos para este crescimento acelerado do número de mortes por ATT no Brasil e, dentre eles, Moysés ${ }^{43}$ aponta cinco: $\left(1^{\circ}\right)$ o veículo é visto e usado pelo motorista brasileiro como instrumento de poder; $\left(2^{\circ}\right)$ ao mesmo tempo em que critica-se a infração de trânsito cometida pelo outro, comete-se a mesma infração em situação semelhante; $\left(3^{\circ}\right)$ o costume de menosprezar as leis de trânsito levando a quem possui automóvel a vê-las como transgressivas em si mesmas; $\left(4^{\circ}\right)$ beber e dirigir, seja por oportunidade ou necessidade, é “normal" no Brasil; e $\left(5^{\circ}\right)$ a pressão produtiva oriunda de algumas profissões, como condutores de veículos de carga, por exemplo, levam ao consumo de estimulantes e a (prováveis) acidentes.

\subsection{Do perfil das vítimas}

Pelas tabelas anteriormente apresentadas, e que demonstraram um aumento significativo de ATT em algumas categorias, em especial a dos motociclistas, é de se supor que, com o aumento anual dos números de AT, essa categoria continuasse liderando, pois o perfil dos condutores não mudaria se não muda a forma de enquadrá-los.

\footnotetext{
${ }^{41}$ WAISELFISZ, op. cit., p. 20.

42 WAISELFISZ, op. cit., p. 21.

${ }^{43}$ MOYSÉS, op. cit., p. 2242.
} 
Segundo o Mapa da Violência no Trânsito ${ }^{44}$, a menor média etária corresponde à categoria dos motociclistas, ou seja, cada vítima de ATT desta categoria tem, em média, 32 anos e 9 meses de idade. Ademais, insta registrar que, nesta categoria, pouquíssimos são os casos de vítimas dos extremos etários (a faixa que corresponde às crianças e idosos), de onde se pode concluir que os ATT estão ceifando a vida dos nossos jovens, pais de família, da população economicamente ativa do país.

A tabela abaixo apresenta todas as médias etárias e categorias envolvidas nos ATT:

Tabela 4 - Média etária das vítimas de AT por categoria

\begin{tabular}{|l|c|}
\hline \multicolumn{1}{|c|}{ CATEGORIA } & MÉDIA ETÁRIA \\
\hline PEDESTRE & 60,9 \\
\hline CICLISTA & 47,2 \\
\hline MOTOCICLISTA & 32,3 \\
\hline AUTOMÓVEL & 39,3 \\
\hline TRANSPORTE DE CARGA & 40,9 \\
\hline ÔNIBUS Fonte: Mapa da Violência no Trânsito - 2013. ${ }^{45}$ & 43,1 \\
\hline
\end{tabular}

Conforme tabela, a segunda categoria com vítimas com mais idade é a dos automóveis $(39,3)$, seguida por transporte de carga, ônibus e ciclistas.

Por fim, observa-se que, dentre todas as categorias apresentadas na tabela acima, a que apresentou maior média etária foi a dos pedestres, o que não a torna menos preocupante, apenas por não envolver diretamente condutores e/ou veículos automotores, pois quem figura nesta categoria é a população idosa, população esta que goza (ou deveria gozar) de maior atenção pela sociedade (população motorizada) e pelo Estado.

\subsection{Dos custos hospitalares dos acidentes}

Segundo informações do SIH, órgão do Ministério da Saúde, o número de internações hospitalares por AT no ano de 2011 chegou a 159.327, as quais geraram para o Sistema Único de Saúde (SUS) um gasto superior a 210,8 milhões de reais.

Como em todos os outros aspectos apresentados, mais uma vez, a categoria dos motociclistas lidera também este ranking, sendo a que mais gerou gastos no ano de 2011, respondendo por quase metade de todo gasto anual (mais de 48\%), referente a mais de 102

\footnotetext{
${ }^{44}$ WAISELFISZ, op. cit., p. 69.

${ }^{45}$ WAISELFISZ, op. cit., p. 69.
} 
A EDUCAÇÃO PARA O TRÂNSITO COMO FERRAMENTA DE OBEDIÊNCIA AOS PRINCÍPIOS DA EFICIÊNCIA E DA DIGNIDADE DA PESSOA HUMANA

Paulo Rangel araújo Ferreira, Itamar da Silva Santos Filho

milhões de reais em internações hospitalares custeadas pelo SUS. Abaixo estão apresentados todos os valores por categoria:

Tabela 2 - Custos de internações hospitalares pagas pelo SUS (ano 2011)

\begin{tabular}{|l|r|c|}
\hline \multicolumn{1}{|c|}{ CATEGORIA } & CUSTO R\$ & \% \\
\hline PEDESTRE & 54.882 .873 & 26,0 \\
\hline CICLISTA & 9.036 .625 & 4,3 \\
\hline MOTOCICLISTA & 102.071 .861 & 48,4 \\
\hline AUTOMÓVEL & 25.907 .141 & 12,3 \\
\hline TRANSPORTE DE CARGA & 1.515 .367 & 0,7 \\
\hline ÔNIBUS & 551.273 & 0,3 \\
\hline OUTROS - sem dados & 16.785 .344 & 8,0 \\
\hline TOTAL & 210.750 .485 & 100,0 \\
\hline
\end{tabular}

A guisa de informação, vale acrescentar, que o SUS responde por $80 \%$ das internações hospitalares do país, outros $20 \%$ vão para a rede privada. Ademais, os supracitados números, correspondem apenas aos ATT mais graves, que demandam internações, acidentes menos graves ou que demandem pouco atendimentos e, até mesmos, procedimentos pré e pós atendimento, não estão inclusos nestes dados, a tabela refere-se apenas às efetivas internações de vítimas de ATT mais graves. ${ }^{47}$

Por fim, cabe dizer que há inúmeros outros gastos oriundos dos ATT que também devem ser considerados, ou seja, além dos físicos, os psicológicos, os materiais, (veiculares ou não), indenizatórios e previdenciários, pois, conforme Rolim "atualmente, cerca de um milhão de benefícios pagos pelo Instituto Nacional do Seguro Social (INSS) são destinados a vítimas de acidentes de trânsito. Isso representa uma despesa de mais de R\$ 12 bilhões para os cofres do INSS". ${ }^{48}$

\section{CONCLUSÃO}

É cediço que o trânsito em condições seguras é um direito fundamental de segunda dimensão, consagrado no texto constitucional e reafirmado por toda a legislação de trânsito. Por isso, com base em todo o exposto, pode-se afirmar que Educação, Engenharia e Legislação de

\footnotetext{
${ }^{46}$ WAISELFISZ, op. cit., p. 79.

47 WAISELFISZ, op. cit., p. 79.

48 BRASIL. Ministério da Previdência Social. CNPS: acidentes de trânsito representam uma despesa de 12 bi para a previdência. Disponível em: <http://www.previdencia.gov.br/noticias/cnps-acidentes-detransito-representam-uma-despesa-de-12-bi-para-a-previdencia/> Acesso: 21 abr. 2015.
} 
A EDUCAÇÃO PARA O TRÂNSITO COMO FERRAMENTA DE OBEDIÊNCIA AOS PRINCÍPIOS DA EFICIÊNCIA E DA DIGNIDADE DA PESSOA HUMANA

Paulo Rangel araújo Ferreira, Itamar da Silva Santos Filho

Trânsito são, portanto, o que se pode apontar como soluções para os altos índices de ATT no Estado brasileiro, tendo por fundamento:

Primeiro, o brasileiro já se acostumou a desrespeitar a legislação de trânsito, o que denota necessidade de investimento em Educação para o Trânsito na formação dos futuros motoristas, antes de qualquer coisa. Pois, se a própria LDB prevê que é na fase de ensino fundamental que a criança deve aprender os valores que guia a sociedade e a família, e é no ensino médio que estes valores serão aprofundados (conforme detalhado na tabela 1), não seria esse o período correto para ensiná-los os valores e regras básicas a serem obedecidos também no trânsito?

Segundo, Educação para o Trânsito por si só não funcionaria, assim como melhora na engenharia e na legislação/fiscalização, isoladamente, também não. Como dito, uma gama de ações precisam estar envolvidas e, dentre elas, essencialmente, a indústria de produção de veículos, de engenharia viária e de mobilidade urbana precisam fazer parte.

Terceiro, fiscalização e punição certa ('certa' no sentido de que a sanção será mesmo aplicada, sem nenhuma chance de transação da pena) dos que transgredirem as leis de trânsito, pois é a certeza de ser punido que deve afastar o homem do crime, como outrora disse Foucault.

Este trabalho procurou demonstrar, através do método lógico-dedutivo, que a Educação, Engenharia e Fiscalização, conjuntamente, são a solução para os altos índices de ATT no Brasil. Objetivou, ainda, reavaliar o valor da vida e o respeito à dignidade da pessoa humana a partir do prisma dos números do trânsito nacional, como corolários das ações dos representantes do Poder Executivo que, mesmo sendo conhecedores da previsão constitucional e do diploma de trânsito, não primam por uma política de Educação para o Trânsito que privilegie a vida.

Buscou-se fundamentar toda a discussão protelada em autores das diferentes áreas que envolvem o trânsito, sendo elas o Direito, a Psicologia e a Pedagogia/Psicopedagogia do Trânsito no intuito de tornar a inferência feita pelo trabalho o mais acreditável possível.

Portanto, é com base nos supracitados fatos e com previsão da garantia constitucional do direito de ir e vir em segurança, do direito fundamental de segunda dimensão à segurança no trânsito e, buscando efetivar o que está previsto no art. 76 do CTB, que prevê que a Educação para o Trânsito deverá ser promovida na pré-escola e nas escolas de $1^{\circ}, 2^{\circ}$ e $3^{\circ}$ graus, que buscase sustentar a tese defendida pelo presente trabalho. 
A EDUCAÇÃO PARA O TRÂNSITO COMO FERRAMENTA DE OBEDIÊNCIA AOS PRINCÍPIOS DA EFICIÊNCIA E DA DIGNIDADE DA PESSOA HUMANA

Paulo Rangel araújo Ferreira, Itamar da Silva Santos Filho

\section{REFERÊNCIAS}

ALEXANDRINO, Marcelo et alii. Direito administrativo descomplicado. $22^{\mathrm{a}}$ ed. atual. São Paulo: Método, 2014.

AMARAL, Antônio Carlos Cintra do. O princípio da eficiência no direito administrativo. Revista Diálogo Jurídico, Salvador, CAJ - Centro de Atualização Jurídica, $\mathrm{n}^{\circ}$. 14, junho-agosto, 2002. Disponível em: <http: / / direitopublico.com.br/pdf_14/DIALOGO-JURIDICO-14-JUNHO-AGOSTO2002-ANTONIO-CARLOS-CINTRA-AMARAL.pdf> Acesso em: 27 out. 2014.

ARAÚJO, Lulyver Modesto. Poder de polícia administrativa de trânsito. São Paulo: Letras Jurídicas, 2010.

BRASIL. Comitê Nacional de Educação em Direitos Humanos. Plano nacional de educação em direitos humanos. Brasília: Secretaria Especial dos Direitos Humanos, 2007.

BRASIL. Departamento Nacional de Trânsito (DENATRAN). 100 anos de Legislação de Trânsito no Brasil: 1910 -2010 / Ministério das Cidades, Departamento Nacional de Trânsito, Conselho Nacional de Trânsito. - Brasília: Ministério das Cidades, 2010.

BRASIL. Departamento Nacional de Trânsito (DENATRAN). Educação de trânsito no ensino regular. Disponível: <http://www.denatran.gov.br/download/unidade\%202.pdf> Acesso: $20 \mathrm{abr}$. 2015.

BRASIL. Emenda Constitucional $n^{\circ} 82$, de 17 de julho de 2014. Inclui o § 10 ao art. 144 da Constituição Federal, para disciplinar a segurança viária no âmbito dos Estados, do Distrito Federal e dos Municípios. Disponível em:

<http://www.senado.gov.br/atividade/materia/detalhes.asp?p_cod_mate=115833> Acesso: 24 out. 2014.

BRASIL. LDB: Lei de diretrizes e bases da educação nacional: Lei n 9.394 , de 20 de dezembro de 1996, que estabelece as diretrizes e bases da educação nacional. - $9^{a}$ ed. - Brasília: Câmara dos Deputados, Edições Câmara, 2014.

BRASIL. Ministério da Previdência Social. CNPS: acidentes de trânsito representam uma despesa de 12 bi para a previdência. Disponível em:

<http: / /www.previdencia.gov.br/noticias/cnps-acidentes-de-transito-representam-umadespesa-de-12-bi-para-a-previdencia/> Acesso: 21 abr. 2015.

BRASIL. Saiba como é a divisão do sistema de educação brasileiro. In: Portal Brasil. Disponível em: <http://www.brasil.gov.br/educacao/2014/05/saiba-como-e-a-divisao-do-sistema-deeducacao-brasileiro/view> Acesso: 24 out. 2014.

BRASIL. Secretaria de Educação Fundamental. Parâmetros curriculares nacionais: apresentação dos temas transversais, ética / Secretaria de Educação Fundamental. - Brasília: MEC/SEF, 1997.

DI PIETRO, Maria Sylvia Zanella. Direito Administrativo. 27ª ed. São Paulo: Atlas, 2014. 
A EDUCAÇÃO PARA O TRÂNSITO COMO FERRAMENTA DE OBEDIÊNCIA AOS PRINCÍPIOS DA EFICIÊNCIA E DA DIGNIDADE DA PESSOA HUMANA

Paulo Rangel araújo Ferreira, Itamar da Silva Santos Filho

FREITAS. Juarez. 0 controle dos atos administrativos e os direitos fundamentais. $3^{\text {a }}$ ed. São Paulo: Malheiros: 2004.

HONORATO, Cássio Mattos. Trânsito Seguro: direito fundamental de segunda dimensão. RT 911, ano 100, p. 107-169, set. 2011.

MARINELA, Fernanda. Direito administrativo. $7^{\text {a }}$ ed. Salvador: JusPODIVM, 2013.

MELLO, Celso Antônio Bandeira de. Curso de direito administrativo. $27^{\text {a }}$ ed. rev. e atual. São Paulo: Malheiros, 2010.

MINAYO, Maria Cecília de S. Morre menos quem morre no trânsito?. Revista Ciência \& Saúde Coletiva, Rio de Janeiro, vol. 17, set. 2012.

MOYSÉS, Samuel J. Determinação sociocultural dos acidentes de transporte terrestre (ATT). Revista Ciência \& Saúde Coletiva, Rio de Janeiro, vol. 17, set. 2012.

NEVES, Luiz Octávio Rocha Miranda C. O novo código de trânsito sofre com a impunidade. In: Revista Visão Jurídica, № 81 - 2013. São Paulo: Editora Escala, 2013.

PEREIRA JÚNIOR, Jessé Torres. Comentários à Lei das Licitações e Contratações da Administração Pública. $5^{a}$ ed. Rio de Janeiro: Renovar, 2002.

OLIVEIRA, Alberto. Trânsito brasileiro mata quase como uma guerra do Vietnã a cada ano. Disponível em: <http://www.tribunadabahia.com.br/2012/12/26/transito-brasileiro-mataquase-como-uma-guerra-do-vietnam-cada-ano> Acesso: 23 out. 2014.

ONUBR. Organização das Nações Unidas no Brasil. Década de ação pelo trânsito seguro 20112020 é lançada oficialmente hoje (11) em todo o mundo. Disponível em:

<http: / / www.onu.org.br/decada-de-acao-pelo-transito-seguro-2011-2020-e-lancadaoficialmente-hoje-11-em-todo-o-mundo/> Acesso: 08 nov. 2014.

SARLET, Ingo Wolfgang. A eficácia dos direitos fundamentais. Porto Alegre: Livraria do Advogado, 1998.

SILVA, José Afonso da. Curso de Direito Constitucional Positivo. 25a . ed. São Paulo: Malheiros, 2005.

SOUZA, J. L. de. Sobre a forma e o conteúdo da educação para o trânsito no ensino fundamental. 2010. 124 f. Tese (Doutorado) - Escola de Engenharia de São Carlos - Universidade de São Paulo, São Carlos, 2010.

WAISELFISZ, Julio J. Mapa da violência no trânsito. Rio de Janeiro, FLACSO Brasil; CEBELA, 2013.

Recebido em: 14.10.2015 / Revisões requeridas em: 11.04.2016 / Aprovado em: 17.04.2016 